Eurasian Journal of Educational Research 85 (2020) 225-246

Eurasian Journal of Educational Research
www.ejer.com.tr

\title{
Compliance of Accounting Education Programs with International Accounting Education Standards: The Case of IES 3 in Tunisia
}

Youcef MAMECHE${ }^{1}$, Moha med Ali OMRI², Najet HASSINE ${ }^{3}$

\begin{tabular}{|c|c|}
\hline ARTICLE INFO & A BS TR ACT \\
\hline $\begin{array}{l}\text { Article History: } \\
\text { Received: } 25 \text { Apr. } 2019 \\
\text { Received in revised form: } 06 \text { Jan. } 2020 \\
\text { Accepted: } 11 \text { Jan. } 2020 \\
\text { DOI: } 10.14689 / \text { ejer.2020.85.11 } \\
\text { Keywords } \\
\text { IESs, PLS-SEM, employability skills, } \\
\text { Tunisia }\end{array}$ & $\begin{array}{l}\text { Purpose: International literature shows that } \\
\text { employability skills of accounting graduates are } \\
\text { considered as a major issue in the economies of the 21st. } \\
\text { The literature on accounting education shows that little } \\
\text { research has been conducted on Arab students in the } \\
\text { North Africa region. Studies on accounting education } \\
\text { research have used different techniques and methods, } \\
\text { but Partial LeastSquares-Structural Equation Modeling } \\
\text { (PLS-SEM) has gained very little concern. The present } \\
\text { study aims to empirically assess the employability skills } \\
\text { of accounting graduates under Accounting International } \\
\text { Education Standards (IESs) in Tunisia as a MENA } \\
\text { country. }\end{array}$ \\
\hline
\end{tabular}

Research Methods: In this study, cross-sectional design with a questionnaire survey is adopted to obtain the perception of different respondents. Our study was based on multi-stakeholder analysis and a survey of 419 respondents, including university teachers, professional accountants and recent graduates in Tunisia. PLS-SEM was performed with Lisrel 8.8, using maximum likelihood estimates, to test the hypothesized models.

Findings: The findings showed that the accounting education program in Tunisia allowed the development of intellectual, organizational and general skills significantly. However, interpersonal and communication skills were considered as the weak link of the accounting education program in Tunisia with the agreement of all respondents. In addition, divergent views were noted regarding the ability of the Tunisian accounting education program to develop technical and functional skills and personal skills.

Implications for Research and Practice: These findings have implications for accounting academics in different universities, different employers and the target government authorities as well as the target IFAC member bodies.

(C) 2020 Ani Publishing Ltd. All rights reserved

${ }^{1}$ Corresponding Author, College of Business Administration, Northern Border University, Arar 91431, Saudi Arabia, e-mail.cfa9y9@gmail.com, ORCID:https://orcid.org/0000-0001-7329-030X.

${ }^{2}$ College of Business Administration, Northern Border University, Arar 91431, Saudi Arabia, ORCID:https://orcid.org/0000-0002-2717-3994.

${ }^{3}$ Department of accounting, FSEGT, University of Tunis, Tunis, Tunisia, ORCID:https://orcid.org/0000-0003 $\underline{3188-3443 .}$. 


\section{Introduction}

Learner differences have always been the main concern of researchers in the field. Many studies have emphasized the importance of professional skills and the need for their availability in the accounting education program (Jackling \&Keneley, 2011; Milliron, 2012). In addition, a considerable amount of research has emphasized that the improvement of the employability of accounting graduates should be realized by improving the quality of accounting education programs to allow the enhancement of skills (Freeman et al., 2008; Gammie\&Cargill, 2002; Thompson et al., 2008). However, overwhelming body of previous research has shown that professional skills requirements are not met in many countries, such as the United States of America, Great Britain and Australia, but also in Asian countries, such as China, where dissatisfaction about the quality of accounting graduates is relatively disturbing (Albrecht \&Sack, 2000; Bui \&Porter, 2010; Awayiga et al., 2010). These studies have also indicated that, from the perspective of practitioners and employers, accounting education is insufficient to meet the requirements of the accounting profession.

Accordingly, the International Federation of Accountants (IFAC) has created the International Accounting Education Standards Board (IAESB), an independent standard-setting body replacing the former IFAC' Education Committee. The primary mission of IAESB is to establish and evolve international accounting standards for accounting education and oversees their implementation worldwide to ensure enhancing, the quality of the accounting education program at international level (St Pierre \&Rebele, 2014), helping for possible accreditation of the academic program internationally (AACSB, 2013) and providing the necessary competence of professional accountants that is needed by different decision-makers in the economic environment.

Sugahara and Wilson (2013) suggest further academic research on the issues regarding International Education Standards (IESs) due to a lack of awareness and recognition of accounting IESs articles in accounting publications. Indeed, very little empirical research has been conductedon IESs issues for accounting (such as Yusof\&Noh, 2016; Razak, 2016; Frijat\&Shbeilat, 2016; Majzoub\&Aga, 2015; Lucianelli\&Citro; 2018). Moreover, on the one hand, the content analysis method was largely used as a research method in the area of IESs literature (Yusof\&Noh, 2016; Razak, 2016; Frijat\&Shbeilat, 2016). On the other hand, analysis tools were limited only to descriptive statistical tools (Lucianelli\&Citron; 2018), or to the use of the T-test and the ANOVA method (Majzoub\&Aga, 2015).

To our knowledge, international literature shows that no previous studies have empirically researched the issue of employability skills under Accounting IESs in the Tunisian context. Hence, the present paper addresses this deficiency by examining the compliance level of employability skills of accounting graduates with the Accounting IESs in Tunisia as a North African country using the partial least squares-structural equation model. Therefore, our principal research question we consider is as follows: Are employability skills obtained at universities and higher education institutions of accounting in Tunisia in harmony with the Accounting IESs requirements? 
The investigation of the Tunisian context is well-timed since promoting Education quality was at the center of the reforms of the 2011 Tunisian revolution (Eid Mohamed et al., 2016). In this sense, the Organisation for Economic Co-operation and Development (OECD) recommends the improvement of theconnection between vocational and academic programs in Tunisia (OECD, 2015). Furthermore, the recent events in Tunisia related to the Arab spring require further research on the issues concerning the quality of education and skills development (Gyimah-Brempong and Ondiege, 2011).

Moreover, this study is motivated by the report issued by the Centre for Financial Reporting Reform (CFRR, 2011) on "Accountancy Education Benchmarking Study: Albania, Bosnia and Herzegovina, Kosovo, Macedonia FYR, Montenegro and Serbia." The study recommended the development of accounting education through the alignment of academic accounting programs with the needs of the employers and the profession. In addition, it proposed more integration and recognition of local programs at the international level by application for accreditation from an international accreditation organization. It also suggested the development of professional skills in compliance with IESs to reduce the gap between students and the labour market requirements.

This study makes a significant contribution to the accounting education literature as follows. First, this study contributes meaningfully to extend the existing body knowledge of Accounting IESs literature by examining the employability skills compliance level with IESs in the Tunisian context. Results are, therefore, expected to provide a better understanding of compliance with the IESs in different areas of the world on international accounting education issues. Furthermore, this study provides a particular contribution to the accounting education works connected with the Middle East and North Africa (MENA), as many studies were performed on the Western-based accounting education systems, and, therefore, little research has been conducted on Arab students in North Africa region. In addition, Tunisia also represents one of the few areas that are less investigated in international accounting education literature. Finally, our study makes a noteworthy methodological contribution to the Accounting IESs research using the PLS-SEM approach, as the data analysis technique, since it remains underused in the investigation of latent phenomena in the field of accounting research (Hampton, 2015; do Nascimento \&da Silva Macedo, 2016).

To deal with the above research question, this study used a survey of 419 respondents, including university teachers, professional accountants and recent graduates in Tunisia. In addition, the partial least squares-structural equation (PLSSEM) approach has been used to analyze data for hypotheses testing purposes. Although the benefits and the widespread use of Structural Equation Modeling (SEM) in the international literature, the method based on Partial Least Squares (PLS-SEM) is still underused in accounting research (do Nascimento\&da Silva Macedo, 2016). Accordingly, the use of PLS-SEM in this investigation presents an original methodological contribution in Accounting IESs literature. 
Thisstudy is organized as follows. The next section reviews the extant relevant literature on similar research issues about professional skills and international accounting education standards. It also highlights the conceptual framework used in the current study and points out our empirical research hypotheses. Section 3 describes and discusses the research methodology. Section 4 presents our research findings and discussion. The final section concludes the paper.

Research Background, Relevant Literature and Research Hypothesis

\section{Professional Skills under IES 3}

O'Connell et al. (2015) emphasize the importance of developing accounting graduates' professional skills and note that accounting education is principally concerned with developing professional knowledge and professional skills. Under old version of IES 3, Professional Skills and General Education, issued by the IAESB in May 2004 and effective on 1 January 2005, Professional skills are organized into five categories (IFAC, 2008): (i) Intellectual skills- are about the ability of a professional accountant to solve problems, to make decisions, and to exercise professional judgment, (ii) Personal skills- are about the personal attitudes and behaviour of a professional accountant (e.g. self-management, the ability to anticipate and adapt to change, professional skepticism, initiative, influence and self-learning), (iii) Interpersonal and Communication skills- enable a professional accountant to work and interact effectively with others, (iv) Technical and Functional skills- include general skills and specific accounting skills (e.g. IT, reporting, measurement, numeracy, risk analysis and decision modeling, and compliance with regulatory and legislative requirements), (v) Organizational skills- enable professional accountants to achieve the best results and outcomes from people and resources available by working effectively with and within the organization to do his job in an effective manner. However, The Technical and Functional skills had been removed in the revised IES 3 (IAES, 2012), Initial Professional Development - Professional Skills, which is based on the learning outcome approach and effective on 1 July 2015. As a result, professional skills, which are required for a competent professional accountant, become grouped into four competences areas instead of five categories.

Although The IAESB emphasizes the importance of general education, as an essential part, in the development of professional competence of professional accountants, IAESB does not consider general education as a compulsory component and a requirement within the development of professional skills prescribed under the revised IES 3 (IAES, 2012).

\section{Related Literature Review and Research Hypotheses}

There have been many studies addressing the issue of skills acquired under the accounting education system in many countries around the world. In an empirical study focused on three categories of respondents: graduate students, teachers and professional accountants, and aimed at identifying the desired knowledge and skills elements in the accounting education programs to meet the challenges of change in the business environment of China, Lin (2008) showed the existence of six areas of 
knowledge and skills that must be included in the accounting education program, namely: administrative skills, management skills, specialized accounting knowledge, personal characteristics, general knowledge, technical knowledge and basic skills.

In the same vein, Awayiga et al. (2010) assessed the accounting education in Ghana and its positioning from the perspective of employers and graduate students. The findings highlighted gap between accounting education and the work environment. Moreover, results showed that there is a consensus among employers and accounting graduates regarding the need to include professional skills in accounting education programs. They also found that analytical and critical skills actually represent intellectual skills and are the most important among professional qualities that accounting practitioners should acquire. In addition, the authors pointed out that graduate students considered that the technical and functional skills wereless important, while employers believed that communication skills are the least important.

Furthermore, Jackling and Lange (2009) investigated technical and general skills included in the content of the university accounting education from the point of view of graduate students and employers in Australia. They found that employers assume that accounting graduates have technical skills related to accounting practices and procedures, but they demonstrate a clear lack of general skills, such as teamwork, which is purely an organizational skill, and personal communication skills. They also pointed out that there is a gap between the academic educational content and skills needed to develop the accounting profession.

The study of Needle JR (2010) highlighted the significant impact of globalization on both accounting education and accounting educators. In addition, the study demonstrated the importance of the skills that must be acquired by accounting graduates to meet the skill requirements of the accounting profession and the expectations of accounting practitioners and different economic decision-makers (Webb and Chaffer, 2016).

All of these empirical investigations call on the researchers and the intervening parties to find mechanisms that offer skills in academic programs meeting, on the one hand, the needs of the labour market and the nature of the accounting profession on the other hand.

On the other hand, looking at the Accounting Education literature context, we observed that there is very little empirical research on (IESs) issues for accounting. Indeed, focusing on professional and research discourse around accounting IESs in published academic articles, Sugahara and Wilson (2013) found that there is a lack of awareness and recognition of accounting IESs articles in accounting publications, and therefore, suggested further academic research on the issues regarding accounting IESs.

Within the framework of descriptive research, Zenuni and Miti (2017) discussed the importance of the adoption of IESs for accounting and the need forAlbania to implement and comply with IESs. They also highlighted levels of compliance with 
IESs in different countries. Al Jalili and Dhanoon (2010) focused attention on the crucial importance of international accounting education for the development of accounting curricula and the professional skills of accounting graduates at Iraqi universities. Saville (2007) concisely described the framework of the International Education Standards (IESs) for Professional Accountants by explaining the nature and the scope and by setting out the overall requirements of each standard. McPeak et al. (2012) outlined the International Accounting Education Standards and identified the existence of some key factors influencing the development and the application of international accounting education standards, namely: Differing cultures, languages, and social, educational, and legal systems. These factors are considered achallenge for the International Accounting Education Standards Board (IAESB). Furthermore, the study recommended the need to implement these standards (IESs) and to include them in the content of accounting education programs in order to develop and improve the skills of professional accountants in accordance with the requirements of the labour market. The authors also suggested the involvement of accounting educators and practitioners to help the IAESB in assessing and developing accounting education programs.

The content analysis method was widely used to examine the compliance level with International Accounting Education Standards. In this context, Yusof and Noh (2016) conduct a study on the level of compliance with IES 2 among IFAC's member bodies. Findings revealed partial compliance with IES 2 among both developing countries and developed countries. Razak (2016) investigated the compliance level of accounting programs in Saudi universities with the International Accounting Education Standards (IAES) in the development of study plan and curricula. The findings indicated thatexceptfor non-offering a stand-alone course in professional ethics and values, the majority of Saudi universities comply with IES 2. Similarly, Almotairy and Stainbank (2014) found that the professional accounting education system in Saudi Arabia does not fully comply with Accounting IESs requirements. Frijat and Shbeilat (2016) sought to examine the extent to which accounting educations programs in Jordanian universities comply with accounting IES 2 requirements. The findings revealed that Jordanian universities do not comply with IES 2. Further, the study recommended the standardization of accounting education programs at Jordanian universities with accounting IES requirements.

Based on the case study approach, Watty et al. (2013) examined the perception and valuation of International Education Standards (IES) member bodies and academics in three counties in Australia, Japan and Sri Lanka. Their result gave evidence of an acceptable level of awareness of IES and recognition of the value of IES as benchmark standards for accounting education among the professional bodies for the three countries. Besides, language and translation, culture and learning approaches and recognition of countries are the most important obstacles reported by both professional bodies and academics

Using the T-test and the ANOVA as statistical analysis tools, Majzoub and Aga (2015) investigated the gap between accounting educational system and practice in Lebanon with reference to the International Accounting Education Standards (IAESs) 
in general, by surveying recent graduates, professors, department heads, employees and employers. The empirical findings showed that professors and employers have the same perceptions of non-compliance of professional competencies with IAESs requirements. In addition, technical competencies are seen by employers as are not at the level required by IAESs. Furthermore, students' perceptions were considered as being overestimated concerning professional and technical competencies.

Limited to descriptive statistical tools of 21 interviewees, Lucianelli and Citro (2018) investigated empirically the professional accountants' views on the level of compliance of Italian university programs with the International Education Standard (IES2). The finding indicated that Italian university programs did not comply with all the requirements of IES2.

Although this little body of empirical research which deals with the IESs issues for accounting, it is noted that, to the best of our knowledge, no previous research hasempirically investigated the IESs for accounting in the Tunisian context. Accordingly, this study addresses this deficiency in accounting education works connected with the Middle East and North Africa (MENA) using the PLS-SEM approach as an original statistical tool in the accounting IESs literature.

Based on the conceptual framework reported above and findings from prior research, it would seem that enhancing employability of accounting graduates in Tunisia requires the design of an accounting education program enabling the development of professional skills specified under the IES 3 (Chatman, 1991; Freeman et al., 2008; Gammie\&Cargill, 2002; Thompson et al., 2008). Hence, the need to investigate the compliance professional skills, obtained at universities and higher education institutions of accounting in Tunisia, with the IES3. Therefore, the following hypotheses were proposed:

H1: The higher education of accounting currently applied in Tunisia allows accounting graduates to develop intellectual skills.

H2: The higher education of accounting currently applied in Tunisia allows accounting graduates to develop technical and functional skills.

H3: The higher education of accounting currently applied in Tunisia allows accounting graduates to develop personal skills.

H4: The higher education of accounting currently applied in Tunisia allows accounting graduates to develop interpersonal and communication skills.

H5: The higher education of accounting currently applied in Tunisia allows accounting graduates to develop organizational and business management skills.

H6: The higher education of accounting currently applied in Tunisia allows accounting graduates to develop general skills.

Figure 1 provides an overview of the study's proposed theoretical model regarding professional skills to be tested in this study. 


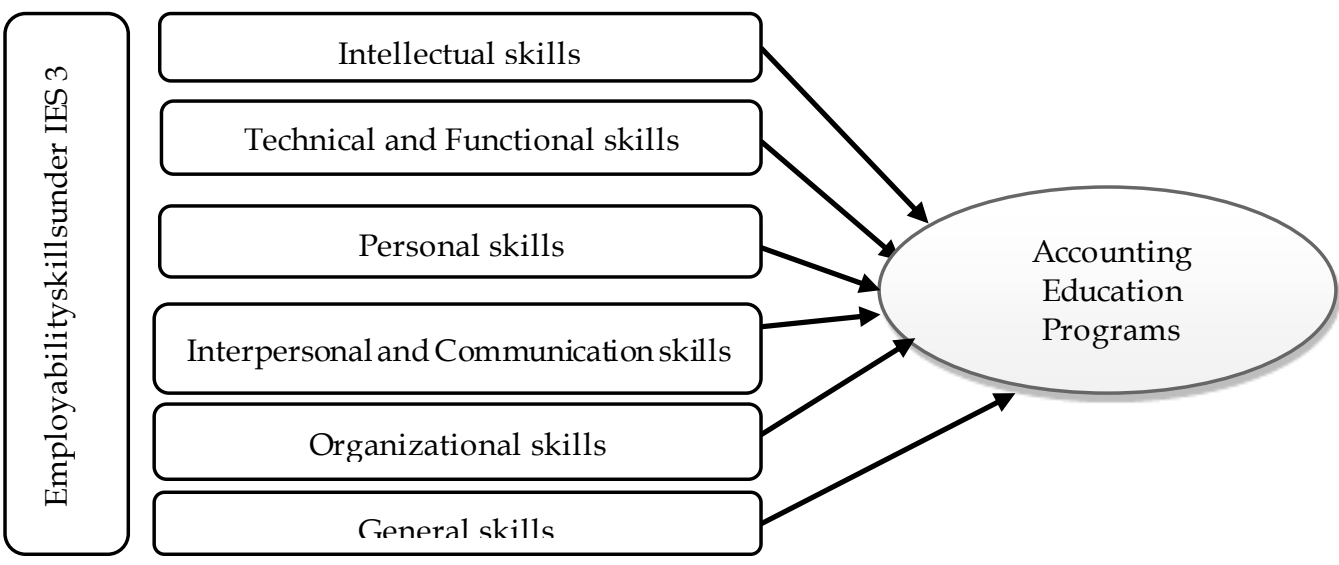

Figure 1. General Theoretical Model and Research Hypotheses.

\section{Method}

\section{Research Design}

A quantitative approach was selected to assess the employability skills of accounting graduates under IESs in the Tunisian context (as depicted in Figure 1 above). This research was designed as a cross-sectional design with a questionnaire survey to obtain the perception of different respondents and the Partial Least Square Structural Equation Modeling (PLS-SEM) was adopted to verify our six hypotheses.

\section{Research Sample}

The target population for this study is composed of the accounting teachers in higher education institutions of accounting in Tunisia, professional accountants, and recently hired accounting graduates who benefited directly from the process of accounting education in Tunisia. The nature of the study leads us to adopt the convenience nonprobability sampling procedure, a method of sampling frequently used in the studies where variables are quantitative (Etikan et al.,2016) to select easily the most accessible subjects (Marshall,1996).

\section{Data Collection Tool and Research Data}

Data for this study were collected using a specially designed questionnaire, as a research instrument for the measurement of a complicated mental phenomenon, such as opinion and attitudes, in an empirical investigation. The survey questionnaire seeks to measure the attitudes toward professional skills compliance in the accounting education environment of Tunisia using a five-point Likert-type scale, where 1 refers to the lowest score of importance and 5 refers to the highest score of importance.

The survey questionnaire comprises 32 skills developed with reference to IES 3 under the version of 2005 (IFAC, 2008) and also on the basis of the skilled specified in 
previous literature. The survey questionnaire was distributed to atotal of 150 teachers, eightquestionnaires were excluded because it was not valid for statistical analysis and 142 questionnaires were selected for statistical analysis (94.66\%). As for accounting graduates, a total of 150 usable questionnaires out of 150 (100\%) were returned and maintained for statistical analysis. Moreover, 150 survey questionnaires were also sent to professional accountants, and 127 valid questionnaires were returned and adopted $(84.66 \%)$ for data analysis. Thus, this study obtained a valid available sample of 419 respondents out of 460 for a $91.09 \%$ response rate, including university teachers, graduate students and professional accountants.

\section{Data Analysis}

Partial Least Squares-Structural Equation Model (PLS-SEM), with Lisrel 8.8, was conducted to test the research hypotheses. SEM is a statistical tool of data analysis that allows researchers to simultaneously evaluate the validity of measures of a set of constructs (measurement model) using Factor Analysis approach, and to assess the strength of multiple relationships between a set of independent variables and one or more dependent variables (structural Model) using Path Analysis approach (Sarstedt et al.,2014; do Nascimento\&da Silva Macedo, 2016; Chin, 1998). PLS is a flexible SEM technique without a specific assumption about data distribution (Vinzi et al., 2010). It is appropriate in the situation where the sample size is relatively small and/or there is not a considerable amount of available prior theory (Wong, 2013). In addition, it offers better results for exploratory studies purposes because it has aparticular characteristic of running as multiple regression analysis (Hair et al.,2014).

\section{Results}

\section{Descriptive Analysis}

Table 1 displays the demographic characteristics of the respondents, namely accounting teachers, professional accountants and graduate students. Concerning accounting teachers, results highlightedthat the majority of respondents were women $(58.5 \%)$, holding the rank of assistants $(77.5 \%)$, affiliated with the University of Manouba (26.1\%) and with academic experience between fiveand tenyears. Regarding professional accountants, most part of the respondents is composed of men $(72.4 \%)$, acting as independent accountants $(57.5 \%)$ and with an experience that varies between fiveand tenyears. With respect to graduate students, Table 1 showsthat the research sample was composed mainly of men (57.3\%). It also points out that the number of respondents wasalmost the same for each university ( 30 graduate students). It is also revealed that the research sample wascomposed mainly of men (57.3\%). 
Table 1.

The Demographics of the Respondents

\begin{tabular}{|c|c|c|c|c|c|c|}
\hline & \multicolumn{2}{|c|}{ Teachers } & \multicolumn{2}{|c|}{ Professionals } & \multicolumn{2}{|c|}{$\begin{array}{c}\text { Recent } \\
\text { graduates }\end{array}$} \\
\hline & $\begin{array}{l}\text { Freque } \\
\text { nce }\end{array}$ & $\begin{array}{c}\text { Perce } \\
\text { nt }\end{array}$ & $\begin{array}{l}\text { Freque } \\
\text { nce }\end{array}$ & $\begin{array}{c}\text { Perce } \\
\text { nt }\end{array}$ & $\begin{array}{c}\text { Freque } \\
\text { nce }\end{array}$ & $\begin{array}{c}\text { Perce } \\
\text { nt }\end{array}$ \\
\hline \multicolumn{7}{|l|}{ Gender } \\
\hline Male & 59 & 41.5 & 92 & 72.4 & 86 & 41.5 \\
\hline Female & 83 & 58.5 & 35 & 27.6 & 64 & 58.5 \\
\hline Total & 142 & 100 & 127 & 100 & 150 & 100 \\
\hline \multicolumn{7}{|l|}{$\begin{array}{l}\text { University granting the } \\
\text { degree }\end{array}$} \\
\hline University of Manouba & & & & & 30 & 20 \\
\hline University of Tunis & & & & & 30 & 20 \\
\hline University of Carthage & & & & & 30 & 20 \\
\hline $\begin{array}{l}\text { University of Tunis-El } \\
\text { Manar }\end{array}$ & & & & & 31 & 20.7 \\
\hline Private University & & & & & 29 & 19.3 \\
\hline Total & & & & & 150 & 100 \\
\hline \multicolumn{7}{|l|}{ Academic Ranks } \\
\hline Professor & 2 & 1.4 & & & & \\
\hline Associate Professor & 7 & 4.9 & & & & \\
\hline Assistant Professor & 23 & 16.2 & & & & \\
\hline Lecturer & 110 & 77.5 & & & & \\
\hline Total & 142 & 100 & & & & \\
\hline \multicolumn{7}{|l|}{ Function } \\
\hline Chartered Accountant & & & 14 & 11 & & \\
\hline $\begin{array}{l}\text { Independent } \\
\text { Accountant }\end{array}$ & & & 73 & 57.5 & & \\
\hline Chief Accountant & & & 40 & 31.5 & & \\
\hline Total & & & 127 & 100 & & \\
\hline \multicolumn{7}{|l|}{ Experience (years) } \\
\hline$<5$ & 10 & 7 & 20 & 15.7 & & \\
\hline 10-May & 61 & 43 & 32 & 25.2 & & \\
\hline 15-Oct & 45 & 31.7 & 34 & 26.8 & & \\
\hline $15-20$ & 15 & 10.6 & 19 & 15 & & \\
\hline $20-25$ & 7 & 4.9 & 9 & 7.1 & & \\
\hline$>25$ & 4 & 2.8 & 13 & 10.2 & & \\
\hline Total & 142 & 100 & 127 & 100 & & \\
\hline \multicolumn{7}{|l|}{ University Affiliation } \\
\hline University of Manouba & 37 & 26.1 & & & & \\
\hline University of Tunis & 21 & 14.8 & & & & \\
\hline University of Carthage & 16 & 11.3 & & & & \\
\hline $\begin{array}{l}\text { University of Tunis-El } \\
\text { Manar }\end{array}$ & 36 & 25.3 & & & & \\
\hline Private University & 32 & 22.5 & & & & \\
\hline Total & 142 & 100 & & & & \\
\hline
\end{tabular}


Measurement Model Analysis

The measurement model wasevaluated concerningthe reliability and validity test for each construct (Hair et al., 2011). To this end, the reliability and validity analysis for the six latent constructs wereperformed to assess the suitability of the items and the internal structure of the constructs that the research instrument measures.

\section{Reliability and Validity Analysis of Measures}

Cronbach's alpha coefficient is used to test the internal consistency for each construct. The Cronbach's alpha values are above the recommended 0.60 threshold (Bagozzi and Yi, 1988; Fornell and Lacrker, 1981) and rangedfrom 0.66 to 0.94 for all constructs, as shown in Table 2, lending support for the internal consistency of items under each latent construct.

Kaiser-Meyer-Olkin (KMO) coefficient is tested to verify the sampling adequacy for the Exploratory Factor Analysis (EFA) process. It is above Kaiser's recommended threshold of 0.6 (Kaiser, 1974). Bartlett's Test of Sphericity is used to examine whether correlations between items are sufficiently large for the EFA process. It is significant with a $\mathrm{p}$-value of $0.00(\mathrm{p}<0,0005)$, giving a strong proof that the correlation matrix wasnot an identity matrix.

\section{Table 2.}

The Cronbach's Alpha for Latent Constructs

\begin{tabular}{lcccc}
\hline \multicolumn{1}{c}{ Latent Variables } & Items & Teachers & Professionals & $\begin{array}{c}\text { Recent } \\
\text { graduates }\end{array}$ \\
\hline Intellectual skills & 3 & 0,886 & 0,818 & 0,79 \\
Technical and Functional skills & 5 & 0,947 & 0,838 & 0,756 \\
Personal skills & 5 & 0,807 & 0,861 & 0,664 \\
Interpersonal and & 7 & 0,749 & 0,79 & 0,786 \\
Communication skills & 4 & 0,718 & 0,748 & 0,852 \\
Organizational skills & 8 & 0,854 & 0,779 & 0,771 \\
General skills & & &
\end{tabular}

Therefore, the EFA technique with Principle Component Analysis (PCA), as the extraction method, was performed for each latent construct. It is found, as shown in Table 3, that the six latent constructs hadeigenvalues greater than one, providing evidence for the unidimensionality of the scales. Moreover, the percentages of explained variance for each latent construct weremore than $50 \%$ for the three samples (teachers, professional accountants and students) following the threshold recommended by Streiner (1994).

To confirm that the hypothesized model provides a good fit to the data, the Confirmatory Factor Analysis (CFA) process, using Structural Equation Modeling (SEM,) is performed, with Lisrel 8.8, from the factor structure obtained in the EFA (with CPA) and the maximum likelihood method waschosen to estimate all models. 
Table 3.

The Principal Component Analysis of Latent constructs

\begin{tabular}{lcccc}
\hline \multicolumn{1}{c}{ Latent Variables } & Items & Teachers & Professionals & $\begin{array}{c}\text { Recent } \\
\text { graduates }\end{array}$ \\
\hline Intellectual skills & 3 & 81,590 & 83,172 & 82,088 \\
Technical and Functional skills & 5 & 85,024 & 85,871 & 85,168 \\
Personal skills & 5 & 86,430 & 86,458 & 87,345 \\
Interpersonal and & 7 & 91,641 & 94,246 & 92,202 \\
Communication skills & 4 & 86,595 & 86,591 & 87,537 \\
Organizational skills & 4 & 83,302 & 87,526 & 83,172 \\
General Skills & 8 & & & \\
\hline
\end{tabular}

Goodness of Test Results for Measurement Models

The goodness of fit (GOF) indices for the measurement models for all constructs are shown in Table 4 . In fact, several (GOF) indices wereused to assess the confirmatory factor analyses and structural equation models. Weselect the following indices following (Roussel et al., 2002): GFI (Goodness of Fit), AGFI (Adjusted Goodness of Fit), RMSEA (Root Mean Square of Error Approximation), NFI (Normed Fit Index), CFI (Comparative Fit Index), and Chisq/df (relative/normed chi-square).

Table 4.

Goodness of Fit Statistics

\begin{tabular}{cccccc}
\hline $\begin{array}{c}\text { Model- } \\
\text { of- } \\
\text { fitindices }\end{array}$ & $\begin{array}{c}\text { Level of } \\
\text { Acceptance }\end{array}$ & Literature & Teachers & Professionals & $\begin{array}{c}\text { Recent } \\
\text { graduates }\end{array}$ \\
\hline GFI & $>.90$ or $>.95$ & $\begin{array}{c}\text { (Miles and } \\
\text { Shevlin, } \\
\text { 1998) }\end{array}$ & 0,91 & 0,89 & 0,88 \\
\hline AGFI & $\geq .90$ & $\begin{array}{c}\text { (Hooper et } \\
\text { al., 2008). }\end{array}$ & 0,88 & 0,86 & 0,83 \\
\hline RMSEA & $<.08$ & $\begin{array}{c}\text { (MacCallum } \\
\text { et al., 1996) }\end{array}$ & 0,075 & 0,067 & 0,077 \\
\hline NFI & $>.90$ & $\begin{array}{c}\text { (Bentler and } \\
\text { Bonnet, } \\
\text { 1980) }\end{array}$ & 0,87 & 0,83 & 0,78 \\
\hline CFI & $\geq .90$ & $\begin{array}{c}\text { (Bentler, } \\
\text { 1990) }\end{array}$ & 0,84 & 0,81 & 0,74 \\
\hline Chisq/df & $<5.0$ & $\begin{array}{c}\text { (Wheaton et } \\
\text { al., 1977) }\end{array}$ & 1,79 & 1,56 & 1,88 \\
\hline
\end{tabular}

The findings reveal that all the values of fitness indices werewithin or close to the acceptable range and, therefore, satisfy the level of acceptance. In the category of absolute fit, the value of RMSEA is lower than 0.08 (Shevlin and Miles, 1998). The value 
of GFI wasgreater than 0.90 for the teacher's measurement model and close to 0.90 for the other measurement models (professionals and graduates). In the category of incremental fit, the value of CFI and NFI werealso close to 0.90 (Bentler and Bonnet, 1980; Bentler, 1990). In the category of parsimonious fit, the value of chisq/dfwaslower than 5.0 (Wheaton et al., 1977). Thus, those indices give evidence for a good fit between the model and the observed data.

\section{Convergent Validity and Construct Reliability Results of Measurement Models}

Table 5 summarizes Convergent Validity (CV) and Construct Reliability (CR) results for the three models. Convergence validity, which refers to the degree of agreement between two or more indicators of the same latent variable (Campbell and Fiske, 1959), wasassessed, for the three models, based on the Average Variance Extracted (AVE).

As clearly shown in Table 5, the values of AVE for all constructs exceeded the cutoff value of 0.50 suggested by Hair et al. (2010), indicating, therefore, that of the measurement models are well measured and explained by its observed variables. In addition, all 32 items, assigned to the six factors, indicated acceptable factor loadings over 0.5 (Johnson et al. 2001; Awang, 2015). On the other hand, Jöreskog's rho was calculated to assess the construct reliability for the three models, the recommended level, which should be greater than 0.70 (Chin, 1998), wassatisfied since Jöreskog's rho coefficient for the six factors ranged from 0.83 through 0.93 as shown in Table 5 .

Table 5.

Convergent Validity (CV) and Construct Reliability (CR) Statistics

\begin{tabular}{|c|c|c|c|c|c|c|c|}
\hline \multirow[b]{2}{*}{$\begin{array}{c}\text { Latent Variables } \\
\text { (Measurement Model) }\end{array}$} & \multirow[b]{2}{*}{ Items } & \multicolumn{2}{|c|}{ Teachers } & \multicolumn{2}{|c|}{ Professionals } & \multicolumn{2}{|c|}{$\begin{array}{l}\text { Recent } \\
\text { graduates }\end{array}$} \\
\hline & & CR & $\mathrm{CV}$ & CR & $\mathrm{CV}$ & CR & $\mathrm{CV}$ \\
\hline Intellectual skills & 3 & 0,898 & 0,75 & 0,834 & 0,637 & 0,863 & 0,684 \\
\hline $\begin{array}{l}\text { Technical and Functional } \\
\text { skills }\end{array}$ & 5 & 0,845 & 0,775 & 0,923 & 0,708 & 0,934 & 0,742 \\
\hline Personal skills & 5 & 0,927 & 0,712 & 0,907 & 0,664 & 0,916 & 0,69 \\
\hline $\begin{array}{l}\text { Interpersonal and } \\
\text { Communication skills }\end{array}$ & 7 & 0,967 & 0,829 & 0,962 & 0,781 & 0,944 & 0,709 \\
\hline Organizational skills & 4 & 0,928 & 0,724 & 0,89 & 0,673 & 0,888 & 0,669 \\
\hline General Skills & 8 & 0,942 & 0,672 & 0,938 & 0,658 & 0,93 & 0,629 \\
\hline
\end{tabular}

\section{Results of Hypotheses Testing and Discussion}

Means and Weights Results of Professional Skills

Table 6 provides means and weights statistics regarding the six professional skills. This descriptive analysis allowed a better description of the extent of the contribution of the Tunisian accounting education in the development of skills laid down by IES3. 
The results indicated that there wereno significant differences in means and weight between the three samples (Teachers, Professional accountants and student graduates). Moreover, according to the respondents of the three samples, the skills the most conveyed by the higher education institutions in Tunisia are personal skills with a mean score close to 4 out of 5 . Next cameorganizational skills, general skills, technical and functional skills and intellectual skills. The second remarkable result wasthe low importance that higher education in Tunisia seemedto give to interpersonal and communication skills in the view of the respondents. In fact, the mean score wasless than 3 and close to 2 out of 5 for the three samples.

Table 6.

Means and Weights of Professional Skills

\begin{tabular}{|c|c|c|c|c|c|c|c|}
\hline \multirow{2}{*}{$\begin{array}{l}\text { professional } \\
\text { skills }\end{array}$} & \multirow[b]{2}{*}{$\begin{array}{c}\text { Item } \\
\mathrm{s}\end{array}$} & \multicolumn{2}{|c|}{ Teachers } & \multicolumn{2}{|c|}{ Professionals } & \multicolumn{2}{|c|}{$\begin{array}{c}\text { Recent } \\
\text { graduates }\end{array}$} \\
\hline & & $\begin{array}{c}\text { Mea } \\
\text { n }\end{array}$ & $\begin{array}{c}\text { Weigh } \\
t\end{array}$ & $\begin{array}{c}\text { Mea } \\
\text { n }\end{array}$ & $\begin{array}{c}\text { Weigh } \\
t\end{array}$ & $\begin{array}{c}\text { Mea } \\
\text { n }\end{array}$ & $\begin{array}{c}\text { Weigh } \\
t\end{array}$ \\
\hline Intellectual skills & 3 & 3,5 & $70 \%$ & 3,5 & $70 \%$ & 3,51 & $70 \%$ \\
\hline $\begin{array}{l}\text { Technical and } \\
\text { Functional skills }\end{array}$ & 5 & 3,76 & $75 \%$ & 3,8 & $76 \%$ & 3,76 & $75 \%$ \\
\hline $\begin{array}{l}\text { Personal skills } \\
\text { Interpersonal and }\end{array}$ & 5 & 3,85 & $77 \%$ & 3,88 & $77 \%$ & 3,82 & $76 \%$ \\
\hline $\begin{array}{l}\text { Communication } \\
\text { skills }\end{array}$ & 7 & 2,22 & $44 \%$ & 2,21 & $44 \%$ & 2,27 & $45 \%$ \\
\hline $\begin{array}{l}\text { Organizational } \\
\text { skills }\end{array}$ & 4 & 3,82 & $76 \%$ & 3,86 & $77 \%$ & 3,79 & $76 \%$ \\
\hline General Skills & 8 & 3,78 & $75 \%$ & 3,83 & $76 \%$ & 3,75 & $75 \%$ \\
\hline
\end{tabular}

\section{Structural Model Analysis: Test of Hypotheses}

PLS-SEM was performed with Lisrel 8.8, using maximum likelihood estimates, to test the hypothesized models in assessing the extent to which the higher education of accounting currently applied in Tunisia allows accounting graduates to develop professional skills in compliance with IES 3. The assessment of the structural model implies that the individual path coefficients must be significant (Hair et al., 2011). The findings are displayed in Table 7 , significant causal relationships at 0.05 level are given one asterisk $(*)$. Onthe other hand, insignificant path coefficients are shown in bold. Within this context, the results indicated statistically significant coefficients at level 0.05 for H1, H5 and H6. However, the results didshow that H4 hadinsignificant coefficients for the three samples. Besides, the finding pointed out insignificant coefficients for $\mathrm{H} 2$ from the point of view of teachers and for $\mathrm{H} 3$ from the perspective of professional accountants. 
Youcef MAMECHE-Mohamed Ali OMRI-Najet HASSINE Eurasian Journal of Educational Research 85 (2020) 225-246

Table 7.

PLS-Structural Model: Path Coefficient and t-statistics

\begin{tabular}{|c|c|c|c|c|c|c|}
\hline \multirow{2}{*}{$\begin{array}{l}\text { Hypothesized } \\
\text { relationships }\end{array}$} & \multicolumn{2}{|c|}{ Teachers } & \multicolumn{2}{|c|}{ Professionals } & \multicolumn{2}{|c|}{ Recent graduates } \\
\hline & Coefficient & $\begin{array}{c}\mathrm{T}- \\
\text { value }\end{array}$ & Coefficient & $\begin{array}{c}\mathrm{T}- \\
\text { value }\end{array}$ & Coefficient & $\begin{array}{c}\mathrm{T}- \\
\text { value }\end{array}$ \\
\hline $\begin{array}{l}\text { H1: TAEP }{ }^{* *} \rightarrow \\
\text { Intellectual skills }\end{array}$ & $0,78^{*}$ & 9,36 & $0,31^{*}$ & 2,44 & $0,39 *$ & 2,22 \\
\hline $\begin{array}{l}\text { H2: TAEP } \rightarrow \text { Technical } \\
\text { and } \\
\text { Functional skills }\end{array}$ & 0,18 & 1,03 & $0,37^{*}$ & 3,87 & $0,73^{*}$ & 5,56 \\
\hline $\begin{array}{l}\text { H3: TAE } \rightarrow \text { Personal } \\
\text { skills } \\
\text { H4: TAE } \rightarrow\end{array}$ & $0,52^{*}$ & 5,05 & 0,21 & 1,15 & $0,65^{*}$ & 3,14 \\
\hline $\begin{array}{l}\text { Interpersonal and } \\
\text { Communication skills }\end{array}$ & 0,07 & 0,94 & 0,13 & 0,96 & 0,24 & 1,25 \\
\hline $\begin{array}{l}\text { H5: } \mathrm{TAE} \rightarrow \\
\text { Organizational skills }\end{array}$ & $0,64^{*}$ & 2,47 & $0,66^{*}$ & 5,11 & $0,69 *$ & 4,47 \\
\hline $\begin{array}{l}\text { H6: TAE } \rightarrow \text { General } \\
\text { Skills }\end{array}$ & $0,57^{*}$ & 6,85 & $0,59 *$ & 4,23 & $0,61^{*}$ & 6,07 \\
\hline
\end{tabular}

\section{Discussion, Conclusion and Recommendations}

This paper has empirically evaluated the extent of professional skills compliance with IESs within thecontext of Tunisian accounting education. By reference to the IES 3 and prior research, a hypothesized model was developed by including 32 comprehensive indicators assigned to six skills constructs. The measurement model was empirically tested by SEM using data collected from 419 respondents, including university teachers, graduate students and professional accountants in Tunisia. The results provide sufficient evidence of the extent of compliance with IES 3 concerning the six following skills: intellectual skills, technical and functional skills, personal skills, interpersonal and communication skills, organizational skills and general skills.

As can be observed in Table7, the results show support for H1, the higher education of accounting currently applied in Tunisia allows accounting graduates to develop intellectual skills, by teachers, professional accountants and graduate students with coefficient values of $0.78(\mathrm{~T}$-value $=9.36), 0.31(\mathrm{~T}$-value $=2.44)$ and 0.39 (T-value $=2.22)$, respectively $(\mathrm{p} \leq 0.05)$. Our results are consistent with the findingsreported by Awayiga et al. (2010) and AAA (1986). This result was expected because this type of skill is a critical basis skill for professional accountants given that it focuses on the critical and logical analysis and organization of data allowing the professional accountant to solve problems, make decisions, and exercise professional judgment. In addition, from the point of view of teachers, this skill is considered as the first and the most important professional skill provided by the accounting education program in Tunisia. 
In connection with $\mathrm{H} 2$, the higher education of accounting currently applied in Tunisia allows accounting graduates to develop technical and functional skills; the results provide insights on divergent views about the ability of the accounting education program in Tunisia to develop this kind of skills. In fact, findings regarding professional accountants and graduate students provide robust support for $\mathrm{H} 2$ with significant coefficients values of $0.37(\mathrm{~T}$-value $=3.87)$ and 0.73 ( T-value $=5.56$ ), respectively at 0.05 level. However, results with reference to teachers indicate rejecting $\mathrm{H} 2$ with weak insignificant coefficient value of 0.18 (T-value $=1.03$ ) at 0.05 level implying that accounting education programs in Tunisia do not contribute to the development of technical skills, a result which is consistent with Awayiga et al.'s (2010) findings who considers that this skill is of less importance and calls for an awareness of the need to integrate the practical aspect into the accounting education programs.

In respect of $\mathrm{H} 3$, the higher education programs of accounting, currently applied in Tunisia, allows accounting graduates to develop personal skills, the findings point out divergent viewpoints about the contribution of accounting education programs in Tunisia to develop this kind of skills. In this context, findings in relation to teachers and graduate students lend support to $\mathrm{H} 3$ with significant strong coefficients values of 0.52 (T-value $=5.05)$ and $0.65(\mathrm{~T}$-value $=3.14)$, respectively at 0.05 level. On the other hand, results concerning professional accountants indicate rejecting $\mathrm{H} 3$ with a moderate insignificant coefficient value of $0.21(\mathrm{~T}$-value $=1.15)$ at 0.05 level, a result which is in agreement with those reported by Awayiga et al. (2010) and Jackling and Lange (2009). Perception of professional accountants should be considered since they are considered as employers of the beneficiaries (graduate students) of the accounting programs applied by teachers, as upstream assessors, and, therefore, they are more pragmatic and objective, as downstream assessors, in the assessment of outputs of the accounting education programs for improvement purposes.

Moreover, the findings reveal rejection $\mathrm{H} 4$, the higher education programs of accounting currently applied in Tunisia allows accounting graduates to develop interpersonal and communication skills, by teachers, professional accountants and graduate students with almost weak insignificant coefficient values of 0.07 (T-value $=$ $0.94), 0.13(\mathrm{~T}$-value $=0.96)$ and $0.24(\mathrm{~T}$-value $=1.25)$, respectively at 0.05 level, results consistent with those reported by AECC (1990) and Jackling and Lange (2009). Hence, this evidence allows us to conclude that the accounting education programs in Tunisia are not sufficiently developed in this interactive aspect or in compliance with the IES3. In this regard, it is noted that this gab in the Tunisian accounting education was not only raised by teachers and professional accountants, but graduate students are also aware of the weakness of the accounting education program they have pursued to develop their interpersonal and communication skills.

As for H5, the higher education programs of accounting, currently applied in Tunisia, allows accounting graduates to develop organizational and business management skills, the results indicate statistically significant strong coefficients values of $0.64(\mathrm{~T}$-value $=2.47), 0.66(\mathrm{~T}$-value $=5.11)$ and $0.69(\mathrm{~T}$-value $=4.47)$ concerning teachers, professional accountants and graduate students, respectively, so that H5 cannot be supported. These findings are consistent with those of Lin (2008) 
and Hancock et al. (2009). On the contrary, these results were invalidated by Jackling and Lange (2009), who highlighted that the accounting education program did not develop managerial skills.

Finally, the results validate H6, the higher education of accounting, currently applied in Tunisia, allows accounting graduates to develop general skills, as statistically significant strong coefficients were found at 0.05 level for teachers, professional accountants and graduate students with values of 0.57 ( T-value $=6.85)$, $0.59(\mathrm{~T}$-value $=4.23)$ and $0.61(\mathrm{~T}$-value $=6.07)$, respectively. These findings are supported by those reported by Lin (2008), and, in contrast, they contradict with those of Jackling and Lange (2009).

To conclude, these findings provide strong empirical evidence that teachers, professional accountants and graduate students unanimously agree that the accounting education program in Tunisia, as a tool for developing professional skills, allow only the development of intellectual (H1), organizational (H5) and general skills (H6). In contrast, Interpersonal and Communication skills are considered as the weak link of the accounting education program in Tunisia with the agreement of all respondents. In addition, divergent views were noted regarding the ability of the Tunisian accounting education program to develop technical and functional skills and personal skills. On the one hand, teachers, contrary to the view of professional accountants and graduate students, do notlend support that the higher education institutions in Tunisia convey technical and functional skills in compliance with IES3, on the other hand, professional accountants, against the opinion of teachers and graduate students, declared that accounting education program in Tunisia did not contribute to the development of personal skills.

Our paper contributes significantly to fill in the gap in the International Accounting Education Standards research in the context of the Middle East and North Africa (MENA) by offering new empirical evidence that the accounting education program in Tunisia allows the development of intellectual, organizational and general skillssignificantly. However, our research suggests that interpersonal and communication skills are considered as the weak link of the accounting education program in Tunisia with the agreement of all respondents. Additionally, divergent views were noted regarding the ability of the Tunisian accounting education program to develop technical and functional skills and personal skills. Furthermore, Our study providesa methodological contribution to the International Accounting Education Standards research using the PLS-SEM approach, as the data analysis techniquesince it remains underused in the investigation of latent phenomena in the field of Accounting research (do Nascimento\& da Silva Macedo, 2016).

The findings obtained inthis study have many significant implications. First, this studyprovides evidence to the accounting academics in different universities with a view to improving employability skills in their academic programs and to help students to develop internationally recognized professional skills. Second, our findings are also of interest to the employers who are interested to see evidence of reducing the gap between the professional skills developed at the universities and 
those required by potential employers and prospective accounting service providers in particular. Third, we provide very important practical implications as our findings also draw the attention of the target government authorities to revisit their accounting education curriculum to bring it into line with IAESs to meet the needs of the accounting service providers locally and internationally. Fourth, our finding carries implications for the target IFAC member bodies in the interest of a comprehensive understanding of the reality of professional skills compliance with IAESs from different contexts topromote convergence of the international standardized professional skills framework in the accounting education around the world and, therefore, providing competent professional accountants needed by different economic stakeholders in the economic environment.

Our study acknowledges many limitations that need to be considered in analyzing the findings. First, due to the small sample size, we cannot generalize the outcomes to a wider population. Another limitation of this study is that the use of a convenience sampling procedure may cause the problem of sampling biases and affect the consistency of the results. Additionally, this study did not undertake a comparative analysis ofTunisian and overseas students. Forth, the present paper did not consider the perception of the Big 4 accounting firms as a crucial stakeholder in the assessment of professional skills conveyed by universities and their level of compliance with IESs.

Finally, as our study has been conducted in Tunisia as a former French colony in North Africa and, therefore, with French academic cultures, it opens the doors to empirically examine the extent of professional skills compliance with IES3 in AngloSaxon cultures countries in the Middle East and North Africa (MENA) to permit one to compare the results from different cultures and contexts and provide valuable insights on the issue of IESs compliance.

\section{Acknowledgment}

The authors gratefully acknowledge the approval and the support of this research study by the grant no BA-2018-3-9-F-7750 from the deanship of Scientific Research at Northern Border University, Arar, KSA.

\section{References}

Accounting Education Change Commission (AECC). (1990). Objectives of education for accountants: position statement number one, Issues in Accounting Education, 5(2), 307-12.

Albrecht, W.S., \& Sack, R. J. (2000). Accounting education: Charting the course through a perilous future (Vol. 16). Sarasota, FL: American Accounting Association.

Al-Jalili, M., \&Dhanoon, A. (2010). The use of international education standards for the professional accountants in the development of accounting curricula for the bachelor degree in Iraq, Rafidain Development Journal, 32(99), 1-33. 
AlMotairy, O. S., \&Stainbank, L. J. (2014). Compliance with international education standards in Saudi Arabia: Policy and educational implications. Journal of Business Studies Quarterly, 5(4), 5-20

American Accounting Association (AAA), (1986), Committee on the Future Structure, Content and Scope of Accounting Education (The Bedford Committee), Future accounting education: Preparing for the expanded profession, Issues in Accounting Education, Vol. 1(1), pp. 168-195.

Association to Advance Collegiate Schools of Business (AACSB) (2013), Accounting accreditation standards $A 6$ and $A 7$.

Awang, Z. (2015). SEM made simple: a gentle approach to learning Structural Equation Modelling. Bandar BaruBangi: MPWS Rich Publication.

Awayiga, J., Onumah, J., \&Tsamenyi, M. (2010), Knowledge and skills development of accounting graduates: The perceptions of graduates and employers in Ghana, Accounting Education, Vol. 19(1), pp. 139-158.

Bagozzi, R.P.\& Yi, Y. (1988). On the evaluation of structural equation models. Journal of the Academy of Marketing Science, Vol. 16(1), 74-94

Bentler, P. M., \&Bonett, D. G. (1980). Significance tests and goodness of fit in the analysis of covariance structures. Psychological bulletin, 88(3), 588.

Bentler, P.M. (1990). Comparatives fit indexes in structural models. Psychological Bulletin, 107: 238-246.

Bui, B., et Porter, B. (2010), The expectation performancegap in accounting education: an exploratory study, Accounting Education: An international journal, Vol. 19 (1-2), pp. 23-50.

Campbell, D. T. and D. W. Fiske (1959). Convergent and Discriminant Validation by the Multitrait-MultimethodMatrix. Psychological Bulletin, 56, 81-105.

Centre for Financial Reporting Reform (CFRR), 2017. Accountancy Education Benchmarking Study: Albania, Bosnia and Herzegovina, Kosovo, Macedonia FYR, Montenegro and Serbia. Available at: http://siteresources.worldbank.org/EXTCENFINREPREF/Resources/4152117142710 9489814/9765106-1487166467531/benchmarking_study.pdf.

Chin, W. W. (1998). The partial least squares approach to structural equation modeling. Modern methods for business research, Vol. 295(2), 295-336.

Cory, S., \&Pruske, K. (2012), Necessary skills for accounting graduates: An exploratory study to determine what the profession wants, Proceeds of ASBBS Annual Conference: Las Vegas, Vol. 19, pp. 208-218.

do Nascimento, J. C. H. B., \& da Silva Macedo, M. A. (2016). Structural Equation Models using Partial Least Squares: an Example of the Application of SmartPLSR in Accounting Research. Revista de Educação e Pesquisaem Contabilidade, 10(3).

Eid Mohamed, Hannah R. Gerber and SlimaneAboulkacem. (2016). Education and the Arab Spring: Resistance, Reform, and Democracy. Sense Publishers, 1-157.

Esposito Vinzi, V., Trincheral, L., Squillacciotti, S., \& Tenenhaus,M. (2008). REBUS-PLSm A response-based procedure for detecting unit segments inPLS path modeling. Applied Stochastic Models in Business and Industry. 24(5), 439-458. 
Etikan, I., Musa, S. A., \&Alkassim, R. S. (2016). Comparison of convenience samplingand purposive sampling. American Journal of Theoretical and Applied Statistics, Vol. 5(1), pp.1-4.

F. Hair Jr, J., Sarstedt, M., Hopkins, L., \& G. Kuppelwieser, V. (2014). Partial least squares structural equation modeling (PLS-SEM) An emerging tool in business research. European Business Review, 26(2), 106-121.

Fornell, C.\&Lacrker D. F. (1981). Evaluating structural equation models with unobservable and measurementerrors. Journal of Marketing Research, Vol.18(1), 39-50.

Freeman, M., Hancock, P., Simpson, L., \& Sykes, C. (2008), Business as usual : A collaborative and inclusive investigation of existing resources, strengths, gaps and challenges to be addressed for sustainability in teaching and learning in Australian university business faculties, ABDC Scoping Report, March, pp. 1-54.

Frijat, Y.S. A., \&Shbeilat, M. K. (2016). Jordanian Universities and Their Role in the Trend towards the Development of Technical Competence for Accounting Learning Outcomes in Line with IES\# 2. Accounting and Finance Research, 5(2), 20-31

Gammie, B., Gammie, E., \& Cargill, E. (2002), Personal skills development in the accounting curriculum, Accounting Education, Vol. 11(1), pp. 63-78.

Gyimah-Brempong, K. W. A. B. E. N. A., \&Ondiege, P. (2011). Reforming higher education: access, equity, and financing in Botswana, Ethiopia, Kenya, South Africa, and Tunisia. World, 3, 0-20.

Hair, J. F., Ringle, C. M., \&Sarstedt, M. (2011). PLS-SEM: Indeed a silver bullet. Journal of Marketing theory and Practice, 19(2), 139-152.

Hair, Jr., J. F., Black, W. C., Babin, B. J., \& Anderson, R. E. (2010).Multivariate Data Analysis: A global perspective(7th ed.) Upper Saddle River, NJ: Pearson Prentice Hall.

Hampton, C. (2015). Estimating and reporting structural equation models with behavioral accounting data. Behavioral Research in Accounting, 27(2), 1-34.

Hancock, P., Howieson, B., Kavanagh, M., Kent, J., Tempone, I., Segal, N., \& Freeman, M. (2009), The roles of some key stakeholders in the future of accounting education in Australia ,Australian Accounting Review, Vol. 19(3), pp. 249-260.

Hooper, D., Coughlan,J. \& Mullen, M. (2008). Structural equation modelling: guidelines for determining model fit. Electronic Journal of Business Research Methods, Vol. $6(1), 53-60$.

Howieson, B. (2003), Accounting practice in the new millennium: Is accounting education ready to meet the challenge? , The British Accounting Review, Vol. 35(2), pp. 69-103.

International Accounting Education Standards Board (IAES). (2012), Exposure DraftProposed International Education Standard (IES) 3. New York: IFAC.

International Federation of Accountants (IFAC), (2008), International Accounting Education Standards Board : International Education Standards 1-8. August 2008, New York: IFAC, 1-87. 
Jackling, B., \& De Lange, P. (2009), Do accounting graduates' skills meet the expectations of employers? A matter of convergence or divergence, Accounting Education, Vol. 18(4), pp. 369-385.

Jackling, B., \&Keneley, M. (2011), Influence on the supply of accounting graduates in Australia: A focus on international students, Accounting and Finance, Vol. 49(1), pp. 141-160.

Johnson, B. and Stevens, J. J. (2001). Confirmatory factor analysis of the school level environment questionnaire (SLEQ). International Journal of Learning Envrionments Research, 4(3), 325-344.

Kaiser, H.F. (1974) An index of factorial simplicity. Psychometrika, 39, 31-36.

Lin, H. (2008), the development of accounting quality of IAS and IFRS over time: The case of Germany, Journal of International Accounting Research, Vol. 8 (1), pp. 3155.

Lucianelli, G., \&Citro, F. (2018). Accounting Education for Professional Accountants: Evidence from Italy. International Journal of Business and Management, 13(8), 1-15.

MacCallum, R. C., Browne, M. W. \& Sugawara, H., M. (1996). Power analysis and determination of sample size for covariance structure modelling. Psychological Methods, Vol. 1(2), 130-49.

Majzoub, S., \& Aga, M. (2015). Characterizing the gap between accounting education and practice: evidence from Lebanon. International Journal of Business and Management, 10(12), 127-151.

Marshall, M. N. (1996). Sampling for qualitative research. Family practice, 13(6), 522-526.

McPeak, D., Pincus, K. V., \&Sundem, G. L. (2012), The International Accounting Education Standards Board: Influencing global accounting education, Issues in Accounting Education, Vol. 27(3), pp. 743-750.

Milliron, V. C. (2012), Communication skills required by accounting graduates: Practitioner and academic perceptions, Accounting Education, Vol.6(2), pp. 93107.

Mohamed, E. K. A., \&Lashine, S. H. (2003), Accounting knowledge and skills and The challenges of a global business environment, Managerial Finance, Vol.29(7), pp. 3-16.

Needle, J.R. (2010), Implementing a framework for the international transfer of accounting technologies , International Journal of Accounting, education and Research, Vol. 12(1), pp. 45-62.

O'Connell, B., Carnegie, G., Carter, A., de Lange, P., Hancock, P., Helliar, C., \&Watty, K. (2015). Shaping the future of accounting in business education in Australia. Melbourne, Australia: CPA.

OECD (2015), Better Policies Series - Tunisia: a reform agenda to support competitiveness and inclusive growth. OECD Publishing, Available at:https://www.oecd.org/economy/Tunisia-a-reform-agenda-to-support competitiveness-and-inclusive-growth.pdf. 
Razak, R. A. (2016). Extent to Which University Complies with IES 2 in the Development of Education Plans and Curricula-Case of Saudi Arabian University. Journal of Business StudiesQuarterly, 8(1), 115-128.

Roussel P., Durrieu F., Campoy E., et EL Akremi A. (2002) Méthoded'équationsstructurelles: Recherche et applications engestion, Economica

Sarstedt, M., Ringle, C. M., Smith, D., Reams, R., \& Hair Jr, J. F. (2014). Partial least squares structural equation modeling (PLS-SEM): A useful tool for family business researchers. Journal of Family Business Strategy, 5(1), 105-115.

Saville, H. (2007). International education standards for professional accountants (IESs). Accounting Education: An International Journal, 16(1), 107-113.

Shevlin, M., \& Miles, J. N. (1998). Effects of sample size, model specification and factor loadings on the GFI in confirmatory factor analysis. Personality and Individual differences, Vol. 25(1), 85-90.

St Pierre, E. K., \&Rebele, J. E. (2014), An agenda for improving accounting education, In R. M. S. Wilson (Ed.), The Routledge companion to accounting education, Oxford: Routledge, pp. 102-121.

Streiner. (1994). figuring out factors: the use and misuse of factor analysis. Canadian Journal of Psychiatry, 39(3), pp. 135-140.

Sugahara, S., \& Wilson, R. (2013). Discourse surrounding the international education standards for professional accountants (IES): a content analysis approach. Accounting Education, 22(3), 213-232.

Thompson, A., Fernandez, M., Budnik, S., \& Boston, A. (2008), APLG Panel on academia and the accounting profession: The Big 4 respond, Accounting Education, Vol 23(2), pp. 199-209.

Watty, K., Sugahara, S., Abayadeera, N., \&Perera, L. (2013). Developing a global model of accounting education and examining IES compliance in Australia, Japan, and Sri Lanka. Accounting Education, 22(5), 502-506.

Webb, J., \& Chaffer, C. (2016), The expectation performance gap in accounting education: A review of generic skills development in UK accounting degrees, Accounting Education, Vol. 25(4), pp. 349-367.

Wheaton, B., Muthen, B., Alwin, D., F. \& Summers, G. (1977). Assessing Reliability and Stability in Panel Models. Sociological Methodology, Vol. 8(1), 84-136.

Wong, K. K. K. (2013). Partial least squares structural equation modeling (PLS-SEM) techniques using SmartPLS. Marketing Bulletin, 24(1), 1-32.

Yusof, R. N., \& Noh, M. M. (2016). Compliance level of international education standards (IES) 2 among the professional accountants bodies. International Journal, 1(2), 5864.

Zenuni, B. R., \& Miti, M. U. (2017). Compliance with International Education Standards of Accounting in European Union Countries, the Case of Albania as An Official Candidate for Accession to The EU. European Journal of Social Science Education and Research, 4(6), 92-99. 